\title{
Enhanced G Protein Activation in Immortalized Lymphoblasts from Patients with Essential Hypertension
}

\author{
Winfried Siffert, Dieter Rosskopf, Albrecht Moritz, Thomas Wieland, Sylvia Kaldenberg-Stasch, Nina Kettler, \\ Kathrin Hartung, Stefan Beckmann, and Karl H. Jakobs \\ Institut für Pharmakologie, Universitätsklinikum Essen, D-45122 Essen, Germany
}

\begin{abstract}
Epstein-Barr virus-immortalized B lymphoblasts obtained from hypertensive patients with enhanced $\mathrm{Na}^{+} / \mathrm{H}^{+}$exchanger activity (HT cells) proliferate distinctly faster upon serum stimulation than those from normotensive controls with low exchanger activity (NT cells) (Rosskopf, D., E. Frömter, and W. Siffert. 1993. J. Clin. Invest. 92:25532559). Stimulation with platelet-activating factor (PAF) as well caused an enhanced proliferation of $H T$ cells. In analyzing possible differences in signal transduction between the immortalized NT and HT lymphoblasts, we observed that cell stimulation with PAF and somatostatin caused a twofold higher increase in $\left[\mathrm{Ca}^{2+}\right]_{i}$ in HT than in NT cell lines. This difference was completely abrogated by pertussis toxin (PTX) treatment. Furthermore, PAF-stimulated formation of inositol 1,4,5-trisphosphate $\left(\mathrm{IP}_{3}\right)$ was twofold enhanced in $\mathrm{HT}$ cell lines. On the other hand, PAF receptor density and affinity, total cellular phospholipase $C$ activity, expression of PTX-sensitive $G$ proteins, and control binding of the stable GTP analogue, guanosine $5^{\prime}-[\gamma$-thio $]$ triphosphate $\left(G_{T P} \boldsymbol{S}\right)$, to membrane $G$ proteins were not different in NT and HT cell lines. However, PAF- and mastoparan-stimulated binding of GTP $\gamma$ S to G proteins, which was fully PTX-sensitive, was 2.5 -fold higher in HT than NT cell lines. These data suggest an enhanced receptor-mediated activation of PTX-sensitive G proteins despite unchanged receptor and $G$ protein expression. Thus, this study not only suggests that enhanced signal transduction and cell proliferation are abnormalities in a certain group of patients with essential hypertension but also explains these findings as a result of an enhanced $G$ protein activation in this common disorder.
\end{abstract}

Winfried Siffert, Dieter Rosskopf, and Albrecht Moritz contributed equally to this work.

Address correspondence to Winfried Siffert, Institut für Pharmakologie, Universitätsklinikum Essen, Hufelandstrasse 55, D-45122 Essen, Germany. Phone: 201-723-3470; FAX: 201-723-5968.

Received for publication 19 January 1995 and accepted in revised form 6 April 1995.

1. Abbreviations used in this paper: anti-sIgM, anti-surface IgM antibody; EH, essential hypertension; $\mathrm{G}$ protein, guanine nucleotide-binding regulatory protein; GTP $\gamma \mathrm{S}$, guanosine $5^{\prime}-[\gamma$-thio $]$ triphosphate; HT, hypertensive; $\mathrm{IP}_{3}$, inositol 1,4,5-trisphosphate; NHE, $\mathrm{Na}^{+} / \mathrm{H}^{+}$exchanger; NT, normotensive; PAF, platelet-activating factor; PIP $_{2}$, phosphatidylinositol 4,5-bisphosphate; PLC, phospholipase C; PTX, pertussis toxin.

J. Clin. Invest.

(c) The American Society for Clinical Investigation, Inc.

0021-9738/95/08/0759/08 \$2.00

Volume 96, August 1995, 759-766
(J. Clin. Invest. 1995. 96:759-766.) Key words: hypertension - calcium • signal transduction - phospholipase C • G proteins

\section{Introduction}

Approximately $30-50 \%$ of all patients with essential hypertension $(\mathrm{EH})^{1}$ display an enhanced activity of the $\mathrm{Na}^{+} / \mathrm{H}^{+}$exchanger (NHE) in blood cells $(1,2)$. We reported recently that this enhanced NHE phenotype persists in Epstein-Barr virusimmortalized lymphoblasts after prolonged cell culture, suggesting that this abnormality is under genetic control (3). We could rule out that this phenomenon is caused by an overexpression of the NHE-1 mRNA and also exclude a mutation in the NHE-1 gene. Moreover, we demonstrated that hypertensive (HT) cell lines, i.e., lymphoblasts obtained from subjects with EH and high NHE activity, proliferate distinctly faster upon serum stimulation than normotensive (NT) cells, i.e., lymphoblasts obtained from normotensive subjects with low NHE activity (3). A more detailed analysis revealed that HT cell lines proceed faster through the cell cycle and are more often found in the $G_{2} / M$ phase than NT controls (4). The high NHE activity is apparently not responsible for the enhanced proliferation of HT cell lines since these cells multiplied faster than NT cells over a broad range of external $\mathrm{pH}$ values, even at alkaline conditions, when NHE does no longer take part in intracellular $\mathrm{pH}$ regulation (4). The serum-stimulated growth of NT and HT cell lines depended, at least in part, on pertussis toxin (PTX)-sensitive guanine nucleotide-binding regulatory proteins ( $G$ proteins) (4). Since serum consists of an undefined mixture of various agonists and growth factors, we performed a detailed characterization of the intracellular signal transduction components and pathways in NT and HT cells using plateletactivating factor (PAF) as a well defined agonist of human lymphoblasts (5-9). We report here that PAF stimulation of HT cell lines results in enhanced proliferation, $\mathrm{Ca}^{2+}$ mobilization, and formation of the second messenger, inositol 1,4,5triphosphate $\left(\mathrm{IP}_{3}\right)$, which is apparently due to an enhanced activation of PTX-sensitive $G$ proteins.

\section{Methods}

Materials. RPMI 1640 medium, inositol-free RPMI 1640 medium, streptomycin, penicillin, and L-glutamine were from GIBCO (Eggenstein, Germany). Fetal calf serum (FCS) was from Vitromex (Vilshofen, Germany), anti-surface IgM antibody (anti-sIgM $\left[\mathrm{Fab}^{\prime}\right]_{2}$ ) from Tago (Burlingame, CA), and Fura-2 acetoxymethylester from Molecular Probes (Eugene, OR). PAF, somatostatin, mastoparan-7, and ionomycin were from Calbiochem (Bad Soden, Germany). PTX, digitonin, soybean trypsin inhibitor, fatty acid-free bovine serum albumin (BSA), peroxidase-conjugated goat anti-rabbit IgG, phosphatidylethanolamine, sodium deoxycholate, Folch fraction I, and phosphatidylinositol 4,5bisphosphate ( $\left.\mathrm{PIP}_{2}\right)$ were from Sigma (Deisenhofen, Germany). All 
nucleotides were from Boehringer Mannheim (Mannheim, Germany). myo- $\left[2-{ }^{3} \mathrm{H}\right]$ inositol $(10 \mathrm{Ci} / \mathrm{mmol}),\left[{ }^{3} \mathrm{H}\right] \mathrm{PIP}_{2}(2 \mathrm{Ci} / \mathrm{mmol})$, [octadecyl9,10- $\left.{ }^{3} \mathrm{H}(N)\right]$ PAF $(150 \mathrm{Ci} / \mathrm{mmol}),\left[{ }^{35} \mathrm{~S}\right]$ guanosine $5 '-[\gamma$-thio $]-$ triphosphate $\left(\left[{ }^{35} \mathrm{~S}\right] \mathrm{GTP} \gamma \mathrm{S}\right)$, and nicotinamide adenine dinucleotide $\left(\left[{ }^{32} \mathrm{P}\right] \mathrm{NAD}^{+} ; 30 \mathrm{Ci} / \mathrm{mmol}\right)$ were from DuPont-New England Nuclear (Bad Homburg, Germany). The anti- $\alpha_{\mathrm{i} \text { common }}$ antiserum AS 266 (10) was kindly provided by Dr. Karsten Spicher (Berlin, Germany).

Cell culture. The establishment of the cell lines has been described in full detail previously (3). Briefly, individuals were selected on the basis of normal diastolic blood pressure and no family history of hypertension or of elevated diastolic blood pressure and at least one hypertensive parent. The second selection criterion was a constant low or high NHE activity in platelets and lymphocytes. For this purpose, we screened several normotensive and hypertensive individuals for NHE activity in platelets. We established two groups of hypertensive patients that could be distinguished based on high or low platelet NHE activity. The high NHE phenotype was only infrequently found in normotensive controls (11). In a second round of selection, the patients with high NHE activity were investigated at least twice for their NHE activity in platelets, lymphocytes, and neutrophils. Only those normotensive controls and hypertensive patients which consistently displayed low or high NHE activity in independent measurements conducted over at least 2 mo were included in the study, i.e., their lymphocytes were immortalized with Epstein-Barr virus. Further details of these subjects have been published previously (3). A total of $10 \mathrm{NT}$ and $10 \mathrm{HT}$ cell lines was established. Cells were routinely maintained in culture in RPMI 1640 medium supplemented with $2 \mathrm{mM}$ L-glutamine, $100 \mathrm{U} / \mathrm{ml}$ penicillin, $100 \mathrm{mg} / \mathrm{ml}$ streptomycin, and $10 \%$ FCS. Passages were performed twice a week, and fresh cultures were established from the frozen stocks every 3-4 mo. For reasons of feasibility, six NT and six HT cell lines, displaying low and high NHE activity as well as normal and enhanced serum-stimulated proliferation, respectively, during a period of $2 \mathrm{yr}$, were randomly chosen for most of the experiments of this investigation. To avoid fortuitous influences of cell culture conditions, we repeated the essential experiments, i.e., $\mathrm{Ca}^{2+}$ mobilization, $\mathrm{IP}_{3}$ formation, $\left[{ }^{35} \mathrm{~S}\right]-$ GTP $\gamma \mathrm{S}$ binding, and proliferation, in a given cell line after a minimum interval of $6 \mathrm{wk}$. Furthermore, for each single experiment, a certain number of NT and HT cell lines was seeded on the same day and used after identical time periods, i.e., all determinations were performed in parallel. Finally, we immortalized some cells from hypertensive subjects and normotensive controls twice and we could definitely rule out that the reported differences result from accidental differences in the immortalization process.

Determination of $\left[\mathrm{Ca}^{2+}\right]_{i}$. Measurements of $\left[\mathrm{Ca}^{2+}\right]_{\mathrm{i}}$ were performed on cells seeded at $1 \times 10^{5}$ cells $/ \mathrm{ml}$ and cultured for $24 \mathrm{~h}$ in serum-free RPMI 1640 medium (12). Cells resuspended at $1 \times 10^{7}$ cells $/ \mathrm{ml}$ in serum-free medium were incubated with $2 \mu \mathrm{M}$ Fura- 2 acetoxymethylester for $30 \mathrm{~min}$ at $37^{\circ} \mathrm{C}$, and pelleted and incubated at a density of $5 \times 10^{7}$ cells $/ \mathrm{ml}$ for $30 \mathrm{~min}$ at $37^{\circ} \mathrm{C}$ in RPMI 1640 medium containing $1 \mathrm{mM} \mathrm{Ca}^{2+}$ to allow for complete hydrolysis of the fluorescent dye. Samples $(\sim 200 \mu \mathrm{l})$ were transferred to Eppendorf tubes, centrifuged, and resuspended in $2 \mathrm{ml}$ of prewarmed $\left(37^{\circ} \mathrm{C}\right)$ buffer, composed of 135 $\mathrm{mM} \mathrm{NaCl}, 5 \mathrm{mM} \mathrm{KCl}, 1 \mathrm{mM} \mathrm{CaCl}, 1 \mathrm{mM} \mathrm{MgCl}, 10 \mathrm{mM}$ glucose, and $20 \mathrm{mM}$ Hepes, $\mathrm{pH} 7.4$, at $37^{\circ} \mathrm{C}$. The cells (final concentration $1 \times$ $10^{6}$ cells $/ \mathrm{ml}$ ) were transferred into cuvettes which were placed into the thermostated $\left(37^{\circ} \mathrm{C}\right)$ cuvette holder of a spectrofluorometer (LS 5B; Perkin-Elmer Corp., Norwalk, CT) equipped with a fast ratio mode device. Cells were excited alternatively at $340 / 380 \mathrm{~nm}$, and emission was recorded at $495 \mathrm{~nm}$. Fluorescence values were sampled every 0.1 s. After establishment of a stable fluorescence baseline, agonist was added. For experiments in $\mathrm{Ca}^{2+}$-free medium, $5 \mathrm{mM}$ EGTA (final concentration) was added $10 \mathrm{~s}$ before agonist addition. $\left[\mathrm{Ca}^{2+}\right]_{\mathrm{i}}$ was calculated as described (8).

Preparation of membranes. Cells seeded at a density of $1 \times 10^{6}$ cells $/ \mathrm{ml}$ in serum-containing RPMI 1640 medium and grown for $1 \mathrm{~d}$ were harvested, washed twice in phosphate-buffered saline, resuspended in ice-cold lysis buffer $(250 \mathrm{mM}$ sucrose, $1.5 \mathrm{mM} \mathrm{MgCl} 2,1 \mathrm{mM}$ ATP, $3 \mathrm{mM}$ benzamidine, $1 \mathrm{mM}$ phenylmethylsulfonyl fluoride, $2 \mu \mathrm{g} / \mathrm{ml}$ soy- bean trypsin inhibitor, and $20 \mathrm{mM}$ Tris $/ \mathrm{HCl}, \mathrm{pH} 7.5$ ), and homogenized by nitrogen cavitation. The cavitate was centrifuged at $2,500 \mathrm{~g}$ for 10 min, and a crude membrane fraction was obtained from the resulting supernatant by centrifugation at $100,000 \mathrm{~g}$ for $20 \mathrm{~min}$. The resulting pellet was washed in a buffer consisting of $1 \mathrm{mM}$ EDTA, $1 \mathrm{mM}$ dithiothreitol, $3 \mathrm{mM}$ benzamidine, $1 \mathrm{mM}$ phenylmethylsulfonyl fluoride, 2 $\mu \mathrm{g} / \mathrm{ml}$ soybean trypsin inhibitor, and $20 \mathrm{mM}$ Tris $/ \mathrm{HCl}, \mathrm{pH} 7.5$, resuspended, and finally stored in the same buffer at $-70^{\circ} \mathrm{C}$. Protein concentration was determined according to Bradford (13), using bovine IgG as a standard.

Phospholipase $C$ (PLC) assay in intact and permeabilized cells. Cells washed once in phosphate-buffered saline and seeded at $2 \times 10^{6}$ cells $/ \mathrm{ml}$ in inositol-free RPMI 1640 medium supplemented with $0.25 \%$ (wt/vol) BSA and $25 \mathrm{mM}$ Hepes, $\mathrm{pH} 7.4$, (labeling medium) were labeled with $5-7 \mu \mathrm{Ci} / \mathrm{ml} m y o-\left[{ }^{3} \mathrm{H}\right]$ inositol for $20-24 \mathrm{~h}$. After centrifugation, resuspension in labeling medium at $2 \times 10^{6} \mathrm{cells} / \mathrm{ml}$, and equilibration for $30 \mathrm{~min}$ at $37^{\circ} \mathrm{C}, \mathrm{LiCl}(20 \mathrm{mM})$ was added, and cells were incubated for an additional $15 \mathrm{~min}$ at $37^{\circ} \mathrm{C}$. Thereafter, cell aliquots ( $400 \mu \mathrm{l}$ ) were stimulated for 15,30 , and $45 \mathrm{~s}$ with PAF ( final concentration $0.1 \mu \mathrm{M})$ dissolved in $100 \mu \mathrm{l}$ phosphate-buffered saline containing $1 \%(\mathrm{wt} / \mathrm{vol}) \mathrm{BSA}$. Controls were incubated for $30 \mathrm{~s}$ with $100 \mu \mathrm{l}$ of solvent. After termination of reactions with $1 \mathrm{ml} 0.6 \mathrm{M} \mathrm{HCl}, 3 \mathrm{ml}$ chloroform/methanol/concentrated $\mathrm{HCl}(200: 100: 0.75$ by vol) was added, the mixtures were vortexed for $30 \mathrm{~s}$, centrifuged, and the aqueous phases were collected and neutralized with $6 \mathrm{ml} 150 \mathrm{mM}$ Tris base. Inositol phosphates were resolved on Dowex AG1-X8 columns $(0.7 \mathrm{ml}$, Bio-Rad Laboratories, Richmond, CA) and analyzed as described (7). In some experiments, cells prepared and labeled as above were permeabilized for $30 \mathrm{~min}$ with $1 \mu \mathrm{M}$ digitonin and then stimulated with 100 $\mu \mathrm{M}$ GTP $\gamma \mathrm{S}$ for $30 \mathrm{~s}$. Thereafter, cells were further processed as described above.

PLC assays in membrane and cytosolic fractions. Mixed phospholipid vesicles containing phosphatidylethanolamine and $\left[{ }^{3} \mathrm{H}\right] \mathrm{PIP}_{2}$ in a molar ratio of 2:1 were prepared by drying the lipids in chloroform/ methanol/water (75:25:2 by vol) and resuspending them in $50 \mathrm{mM}$ Hepes, $150 \mathrm{mM} \mathrm{NaCl}, 2 \mathrm{mM}$ sodium deoxycholate, $\mathrm{pH} 7.0$, followed by sonication on ice. Assays were performed at $37^{\circ} \mathrm{C}$ in a total volume of $70 \mu \mathrm{l}$ containing lipid vesicles ( $\left.50 \mu \mathrm{M}\left[{ }^{3} \mathrm{H}\right] \mathrm{PIP}_{2}, 10,000 \mathrm{cpm}\right), 50$ $\mathrm{mM}$ Hepes, pH 7.0, $150 \mathrm{mM} \mathrm{NaCl}, 5 \mathrm{mM} \mathrm{MgCl}, 10 \mathrm{mM} \mathrm{LiCl}, 3 \mathrm{mM}$ EGTA, $1 \mathrm{mM}$ sodium deoxycholate, and $\mathrm{CaCl}_{2}$ to give a final free $\mathrm{Ca}^{2+}$ concentration of $1 \mu \mathrm{M}$. Reactions started by addition of membranes ( 10 $\mu \mathrm{g}$ of protein) or cytosol (7.5 $\mu \mathrm{g}$ of protein) were conducted for 15 min (membranes) or 2 min (cytosol) and stopped by addition of 100 $\mu 11 \mathrm{M} \mathrm{HCl}, 5 \mathrm{mM}$ EGTA. Under these conditions, $\mathrm{PIP}_{2}$ hydrolysis was linear with time. $5 \mu \mathrm{l}$ of carrier lipid (Folch fraction I, 10-50 nmol of each lipid) was then added, and phase separation was induced by addition of $250 \mu \mathrm{l} \mathrm{chloroform} / \mathrm{methanol} /$ concentrated $\mathrm{HCl}(100: 100: 0.6$ by vol) and vortexing for $15 \mathrm{~s}$. After centrifugation $(13,000 \mathrm{~g}, 5 \mathrm{~min})$, $200-\mu \mathrm{l}$ aliquots of the upper phase were removed for liquid scintillation counting.

Immunoblotting and ADP-ribosylation. Membrane proteins $(50 \mu \mathrm{g})$ were heated for $5 \mathrm{~min}$ at $95^{\circ} \mathrm{C}$ in sample buffer containing $5 \% 2$ mercaptoethanol and fractionated by SDS-PAGE according to Laemmli (14) with $9.5 \%$ acrylamide in the running gel and $4 \%$ acrylamide in the stacking gel. Urea $(6 \mathrm{M})$ was present in part of the running gels to resolve $\alpha_{\mathrm{i} 2}$ from $\alpha_{\mathrm{i} 3}(15)$. Identification of $\mathrm{G}$ proteins was conducted as described in full detail elsewhere (15). PTX-catalyzed ADP-ribosylation of membrane proteins $(25 \mu \mathrm{g})$ was performed in a final assay mixture $(50 \mu \mathrm{l})$ containing $25 \mathrm{mM}$ Tris- $\mathrm{HCl}, \mathrm{pH} 8.0,1 \mathrm{mM}$ EDTA, 10 mM DTT, $1 \mathrm{mM}$ ATP, $0.1 \mathrm{mM}$ GDP, $1 \mu \mathrm{g} / \mathrm{ml} \mathrm{PTX}, 800 \mathrm{nM}\left[{ }^{32} \mathrm{P}\right] \mathrm{NAD}$, and $0.8 \%(\mathrm{vol} / \mathrm{vol}) \mathrm{Lubrol}$ at $32^{\circ} \mathrm{C}$ for $40 \mathrm{~min}(16)$. The reaction was stopped by heating the samples for $5 \mathrm{~min}$ at $95^{\circ} \mathrm{C}$ in sample buffer. Proteins were fractionated by SDS-PAGE (14) with $12 \%$ acrylamide in the separation gel. Part of the separation gels contained deionized urea $(6 \mathrm{M})$ to resolve $\alpha_{\mathrm{i} 2}$ from $\alpha_{\mathrm{i} 3}$. Gels were stained with Coomassie blue, dried in a slab gel dryer, and exposed to Kodak XAR x-ray film for $5 \mathrm{~h}$.

$P A F$ receptor binding. Cells seeded and grown as described for the 
preparation of membranes ( see above) were centrifuged, washed once in phosphate-buffered saline, and resuspended in Hepes-buffered saline (as for measurements of $\left[\mathrm{Ca}^{2+}\right]_{\mathrm{i}}$ ) plus $0.25 \%$ (wt/vol) BSA and counted. Cells $\left(1.5-3 \times 10^{6}\right.$ in a final volume of $1 \mathrm{ml}$ ) were incubated in triplicate with different concentrations $(0.2-20 \mathrm{nM})$ of $\left[{ }^{3} \mathrm{H}\right]$ PAF complexed to $1 \%(\mathrm{wt} / \mathrm{vol}$ ) BSA in the presence or absence of an excess of unlabeled PAF $(1 \mu \mathrm{M})$ for $2 \mathrm{~h}$ at $4^{\circ} \mathrm{C}$ to avoid degradation of PAF by acylhydrolases (17). Thereafter, cells were centrifuged for $3 \mathrm{~min}$ at $13,000 \mathrm{~g}$, the supernatant was aspirated, the remaining cell pellet was solubilized in tissue solubilizer (Solvable; DuPont-New England Nuclear), and radioactivity was determined by liquid scintillation counting. The fraction of the total binding which was displaceable by $1 \mu \mathrm{M}$ unlabeled PAF was regarded as specific (17). The data were subjected to saturation binding isotherm analysis (GraphPad Inplot Software, San Diego, CA) and also plotted according to Scatchard.

$\left[{ }^{35} S\right] G T P \gamma S$ binding to permeabilized $B$ lymphoblasts. Binding of $\left[{ }^{35} \mathrm{~S}\right] \mathrm{GTP} \gamma \mathrm{S}$ to permeabilized $\mathrm{B}$ lymphoblasts cultivated as described for the analysis of PAF receptor binding was quantified as described (18). In brief, cells $\left(1 \times 10^{6}\right.$ cells $\left./ \mathrm{ml}\right)$ in a buffer consisting of 150 $\mathrm{mM} \mathrm{NaCl}, 5 \mathrm{mM} \mathrm{MgCl}, 1 \mathrm{mM}$ EDTA, and $50 \mathrm{mM}$ triethanolamine-

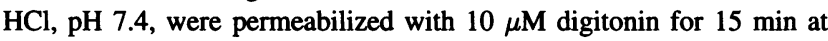
$30^{\circ} \mathrm{C}$ in the presence of $100 \mu \mathrm{M}$ adenosine $5^{\prime}-[\beta, \gamma$-imino $]$ triphosphate and $10 \mu \mathrm{M}$ GDP, followed by addition of PAF $(0.1 \mu \mathrm{M})$, mastoparan$7(25 \mu \mathrm{M})$, or solvent. After $1 \mathrm{~min}$, the suspension was incubated with $10 \mathrm{nM}\left[{ }^{35} \mathrm{~S}\right] \mathrm{GTP} \gamma \mathrm{S}(0.1 \mu \mathrm{Ci} /$ tube $)$ for $10 \mathrm{~min}$. The reaction was terminated by rapid filtration through nitrocellulose filters, which were rinsed three times with $4 \mathrm{ml}$ ice-cold washing buffer consisting of 5 $\mathrm{mM} \mathrm{MgCl}_{2}$ and $50 \mathrm{mM}$ Tris- $\mathrm{HCl}, \mathrm{pH}$ 7.5. The fraction of the total binding that was displaceable by addition of $10 \mu \mathrm{M}$ unlabeled GTP $\gamma \mathrm{S}$ was regarded as specific binding. Each measurement was performed in triplicate.

$\left[{ }^{35} S\right] G T P \gamma S$ binding to membranes. These experiments were conducted as described in full detail elsewhere (19). Briefly, crude membranes ( $3 \mu \mathrm{g}$ protein/tube) prepared as described above were incubated in triplicate for $30 \mathrm{~min}$ at $30^{\circ} \mathrm{C}$ in a buffer consisting of $150 \mathrm{mM} \mathrm{NaCl}$, $5 \mathrm{mM} \mathrm{MgCl}_{2}, 1 \mathrm{mM}$ EDTA, and $50 \mathrm{mM}$ triethanolamine- $\mathrm{HCl}, \mathrm{pH} 7.4$, and various concentrations of $\left[{ }^{35} \mathrm{~S}\right] \mathrm{GTP} \gamma \mathrm{S}$ (range $0.35-100 \mathrm{nM}$ ). The reaction was terminated by rapid filtration through GF/C glass fiber filters, which were rinsed three times with $4 \mathrm{ml}$ ice-cold washing buffer (see above). Binding data were fitted to a one-site competitive binding model and analyzed with the program GraphPad Prism (GraphPad Software).

Cell proliferation. Cells were seeded at an initial density of $2 \times 10^{5}$ cells $/ \mathrm{ml}$ in serum-free medium containing $0.1 \mu \mathrm{M}$ PAF and propagated for $3 \mathrm{~d}$. Cells were counted daily using a CASY cell analyzer system (Schärfe Systems Co., Reutlingen, Germany).

Presentation of data and statistics. All data represent means \pm SD or SEM, as indicated. Data were analyzed using two-tailed Students $t$ test and regarded significantly different at $P<0.05$.

\section{Results}

Effect of PAF on cell proliferation and PAF receptor binding. First, we studied the effect of PAF on proliferation of six NT and six HT cell lines in serum-free medium. NT cells hardly proliferated, whereas a distinct rise in cell count was observed in HT cells upon stimulation with $0.1 \mu \mathrm{M}$ PAF (Fig. $1 A$ ). The mean increase in cell count during $3 \mathrm{~d}$ of culture averaged to a factor of $1.3 \pm 0.3$ in NT compared with $1.8 \pm 0.4$ in HT cell lines $(P<0.05)$. This PAF-induced cell proliferation was partially, by $\sim 50 \%$, prevented in cells pretreated with PTX (100 $\mathrm{ng} / \mathrm{ml}$ for $24 \mathrm{~h}$; data not shown). To study whether this enhanced PAF-induced proliferation in HT cells is a mere reflection of an increased number or affinity of PAF receptors, we measured PAF receptor binding in NT and HT cells using $\left[{ }^{3} \mathrm{H}\right]-$ $\mathrm{PAF}$ as radioligand. PAF receptor densities were calculated at

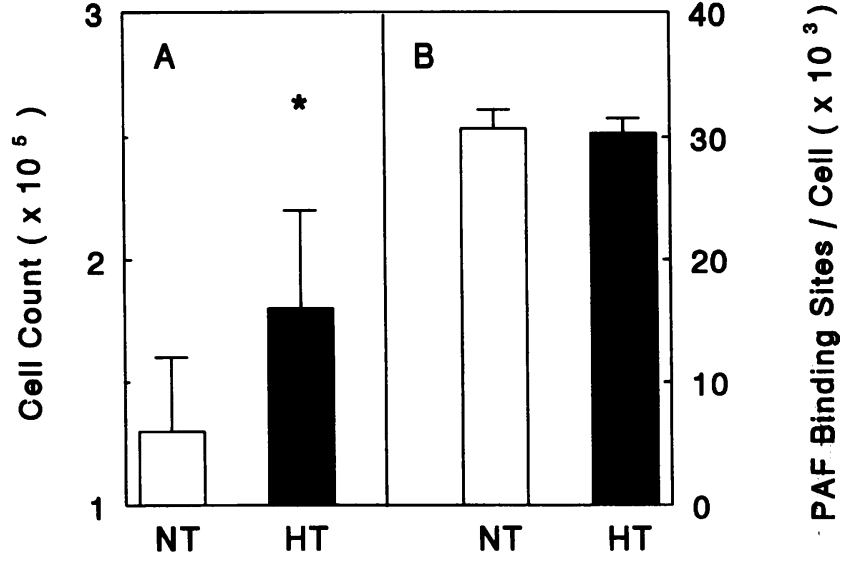

Figure 1. PAF-induced cell proliferation and PAF receptor binding. Proliferation of NT (open column) and HT (closed column) cell lines upon stimulation with PAF $(0.1 \mu \mathrm{M})$ for $3 \mathrm{~d}$ was determined as described in Methods $(A)$. Binding sites of $\left[{ }^{3} \mathrm{H}\right] \mathrm{PAF}$ to NT (open column) and HT (closed column) cell lines were quantified as detailed in Methods $(B)$. Each column represents means \pm SD of experiments performed on six NT and six HT cell lines. $* P<0.05$.

$30,700 \pm 1,500$ and $30,300 \pm 1,200$ (means \pm SD) in NT and HT cells, respectively (Fig. $1 B$ ). From Scatchard plot analysis of [ $\left.{ }^{3} \mathrm{H}\right]$ PAF binding to NT and HT cell lines, similar $K_{\mathrm{d}}$ values of $1.51 \pm 0.16$ and $1.94 \pm 0.35 \mathrm{nM}$ were calculated for NT and HT cells, respectively. Thus, the enhanced PAF-induced proliferation of HT cell lines cannot be ascribed to an enhanced PAF receptor expression or affinity. Therefore, we quantified early events of PAF receptor signaling in NT and HT cell lines.

$\mathrm{Ca}^{2+}$ metabolism in NT and $\mathrm{HT}$ cell lines. The results of $\left[\mathrm{Ca}^{2+}\right]_{\mathrm{i}}$ measurements repeatedly performed in six NT and six HT cell lines are compiled in Fig. 2. Upon stimulation with PAF $(0.1 \mu \mathrm{M})$ in the presence of $1 \mathrm{mM}$ extracellular $\mathrm{Ca}^{2+}$, $\left[\mathrm{Ca}^{2+}\right]_{\mathrm{i}}$ increased by values ranging from 40 to $130 \mathrm{nM}$ and 105 to $250 \mathrm{nM}$ in NT and HT cell lines, respectively (Fig. 2 $A)$. In the absence of extracellular $\mathrm{Ca}^{2+}, \mathrm{PAF}$-induced increases in $\left[\mathrm{Ca}^{2+}\right]_{\mathrm{i}}$ ranged from 15 to $60 \mathrm{nM}$ and 60 to $150 \mathrm{nM}$ in NT and HT cell lines, respectively (Fig. $2 B$ ). Thus, PAF-induced $\left[\mathrm{Ca}^{2+}\right]_{\mathrm{i}}$ increases were higher in HT than NT cell lines under both experimental conditions, and there was virtually no overlap of the values determined in both groups. In contrast, basal values of $\left[\mathrm{Ca}^{2+}\right]_{i}$ were not significantly different in NT and HT cell lines (Fig. $2 \mathrm{C}$ ). In the presence of $1 \mathrm{mM}$ extracellular $\mathrm{Ca}^{2+}$, mean resting values of $\left[\mathrm{Ca}^{2+}\right]_{\mathrm{i}}$ averaged $91 \pm 24$ and $80 \pm 21 \mathrm{nM}$ (means \pm SD; $n=115$ for each group) in NT and HT cell lines, respectively. The PAF-induced rises in $\left[\mathrm{Ca}^{2+}\right]_{i}$ were higher in HT than NT cell lines at all effective concentrations $(0.1 \mathrm{nM}$ to $1 \mu \mathrm{M}$ ) of PAF studied (Fig. $2 \mathrm{D}$ ). Half-maximal effects were observed at $\sim 2 \mathrm{nM} \mathrm{PAF}$, which underscores that receptor affinity for PAF in NT and HT cell lines is not significantly different (see above). At a maximally effective concentration $(0.1 \mu \mathrm{M})$, PAF-induced $\mathrm{Ca}^{2+}$ mobilization, measured in the absence of extracellular $\mathrm{Ca}^{2+}$, was significantly $(P<0.02)$ higher in HT than NT cell lines, with mean rises in $\left[\mathrm{Ca}^{2+}\right]_{\mathrm{i}}$ of $35 \pm 17 \mathrm{nM}$ (mean $\pm \mathrm{SD} ; n=63$ ) and $96 \pm 26 \mathrm{nM}$ (mean $\pm \mathrm{SD}$; $n=73$ ) in NT and HT cells, respectively (Fig. 3 ). In the presence of $1 \mathrm{mM}$ extracellular $\mathrm{Ca}^{2+}$, these values averaged to $89 \pm 29 \mathrm{nM}($ mean $\pm S D ; n=102)$ and $176 \pm 47 \mathrm{nM}($ mean $\pm S D$; $n=140)$ in NT and HT cell lines, respectively. 

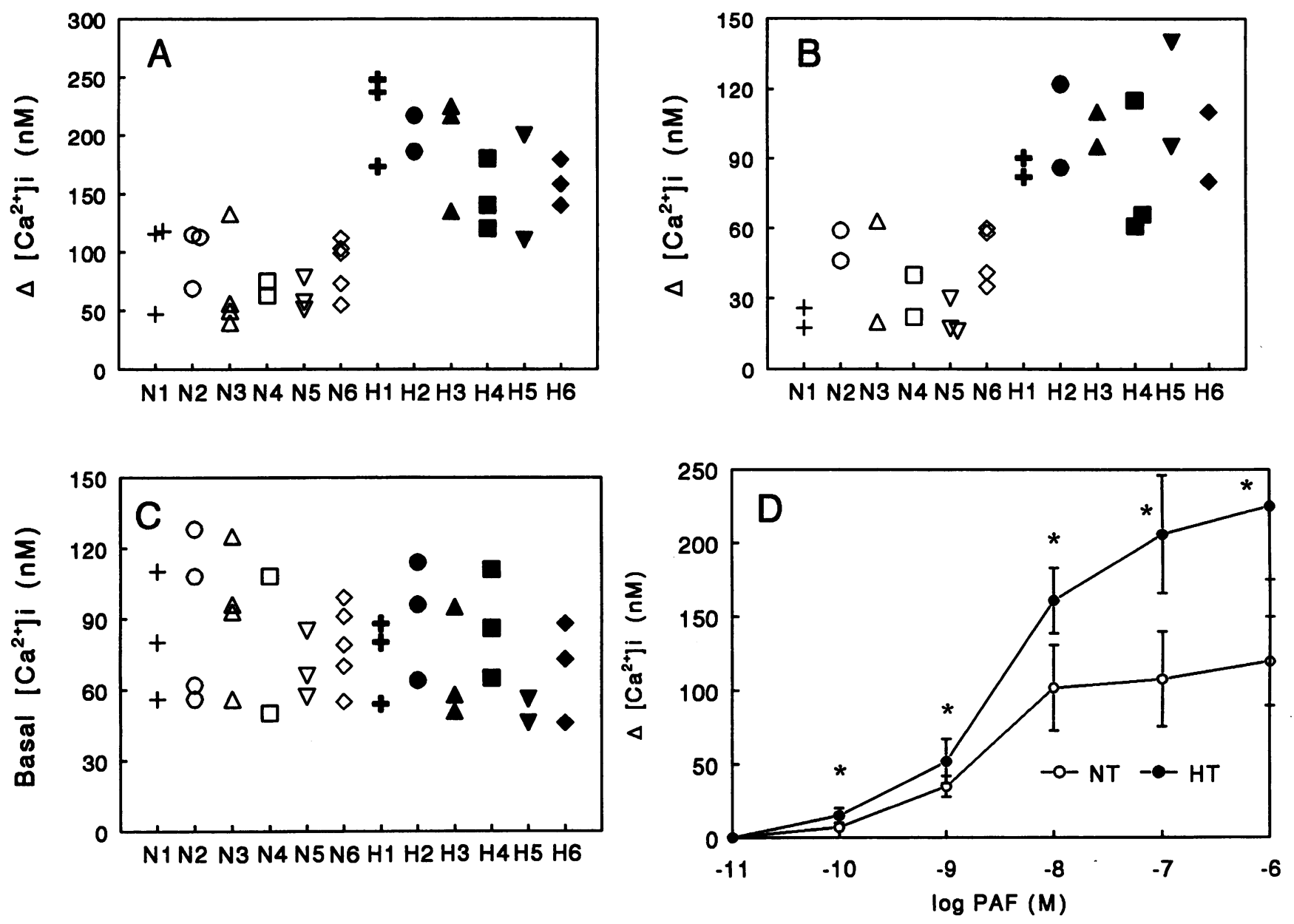

Figure 2. Basal $\left[\mathrm{Ca}^{2+}\right]_{\mathrm{i}}$ and PAF-induced $\left[\mathrm{Ca}^{2+}\right]_{\mathrm{i}}$ increases in different NT and HT cell lines. PAF $(0.1 \mu \mathrm{M})$-induced $\left[\mathrm{Ca}^{2+}\right]_{\mathrm{i}}$ increases $(A$ and $B)$ and basal $\left[\mathrm{Ca}^{2+}\right]_{\mathrm{i}}(C)$ were determined in six different NT (open symbols) and six different HT cell lines (closed symbols) in the presence $(A$ and $C$ ) and absence $(B)$ of $1 \mathrm{mM}$ extracellular $\mathrm{Ca}^{2+}$ as described in Methods. Each symbol represents the average baseline $\left[\mathrm{Ca}^{2+}\right]_{\mathrm{i}}(C)$ or increase in $\left[\mathrm{Ca}^{2+}\right]_{\mathrm{i}}$ above baseline values $(A$ and $B)$ calculated from at least six determinations within one experiment. The number of symbols indicates the total number of independent determinations conducted on the cells from each individual; the interval between the different determinations was at least 2 wk. Concentration-response curves of PAF-induced $\left[\mathrm{Ca}^{2+}\right]_{\mathrm{i}}$ increases $(D)$ were determined in NT $(O)$ and HT $(\bullet)$ cell lines in the presence of $1 \mathrm{mM}$ extracellular $\mathrm{Ca}^{2+}$ at the indicated concentrations of PAF. Mean values $\pm S D$ of rises in $\left[\mathrm{Ca}^{2+}\right]_{i}$ above baseline from three different cell lines each are given. Within one experiment, the effect of each concentration of PAF on $\left[\mathrm{Ca}^{2+}\right]_{i}$ was determined in triplicate. * Significantly different from NT cell lines at $P<0.025$.

To delineate the signal transduction pathway(s) which cause(s) the increased $\mathrm{Ca}^{2+}$ signals in $\mathrm{HT}$ cells, $\left[\mathrm{Ca}^{2+}\right]_{\mathrm{i}}$ increases were evoked by three additional agents (Fig. 3 ). First, the hormonal agent, somatostatin, induced a rapid increase in $\left[\mathrm{Ca}^{2+}\right]_{\mathrm{i}}$ in the immortalized B lymphoblasts. Similar to PAF, somatostatin $(0.1 \mu \mathrm{M})$ caused a significantly $(P<0.02)$ larger increase in $\left[\mathrm{Ca}^{2+}\right]_{\mathrm{i}}$ in HT $(225 \pm 70 \mathrm{nM}$; mean $\pm \mathrm{SD} ; n=33)$ than NT cell lines $(73 \pm 32 \mathrm{nM}$; mean $\pm \mathrm{SD} ; n=30)$. Second, to exclude that the differences in agonist-evoked $\mathrm{Ca}^{2+}$ mobilization were solely due to different filling states of intracellular $\mathrm{Ca}^{2+}$ storage sites, cells suspended in $\mathrm{Ca}^{2+}$-free medium (presence of EGTA) were treated with the $\mathrm{Ca}^{2+}$ ionophore ionomycin, which under these conditions depletes intracellular $\mathrm{Ca}^{2+}$ stores. Ionomycin $(10 \mu \mathrm{M})$ caused a similar rise in $\left[\mathrm{Ca}^{2+}\right]_{\mathrm{i}}$ in NT and HT cell lines, by $202 \pm 30$ and $220 \pm 60 \mathrm{nM}$ (means \pm SD; $n=40$ for each group), respectively. Finally, NT and HT cells were stimulated with an anti-sIgM antibody. Unlike PAF and somatostatin, which act via $\mathrm{G}$ protein-coupled receptors, sig- naling induced by anti-sIgM is mediated by a receptor apparently coupled to intracellular tyrosine kinases (20). Upon stimulation with anti-sIgM $(10 \mu \mathrm{g} / \mathrm{ml}),\left[\mathrm{Ca}^{2+}\right]_{\mathrm{i}}$ increased significantly above baseline but to identical values in NT ( $38 \pm 17 \mathrm{nM}$; mean \pm SD; $n=12)$ and HT cell lines $(42 \pm 10 \mathrm{nM}$, mean $\pm \mathrm{SD}$; $n=14)$. Pretreatment with PTX (100 ng/ml; $24 \mathrm{~h})$ largely reduced, albeit not completely inhibited, both PAF- and somatostatin-induced increases in $\left[\mathrm{Ca}^{2+}\right]_{i}$ in either cell line. Notably, the differences in the magnitude of the $\mathrm{Ca}^{2+}$ signals between NT and HT cell lines were completely abrogated by PTX treatment.

PLC activity in NT and HT cell lines. To investigate whether the different PAF-induced $\mathrm{Ca}^{2+}$ signals in NT and HT cell lines were due to corresponding differences in PAF-stimulated PLC activity, PAF-induced $\mathrm{IP}_{3}$ formation was measured in NT and HT cell lines in several independent experiments. PAF $(0.1$ $\mu \mathrm{M}$ ) increased $\mathrm{IP}_{3}$ formation to $122 \pm 4,123 \pm 4$, and $124 \pm 7 \%$ of unstimulated controls at 15,30 , and $45 \mathrm{~s}$, respectively, in HT cell lines. In NT cell lines, the corresponding values were 


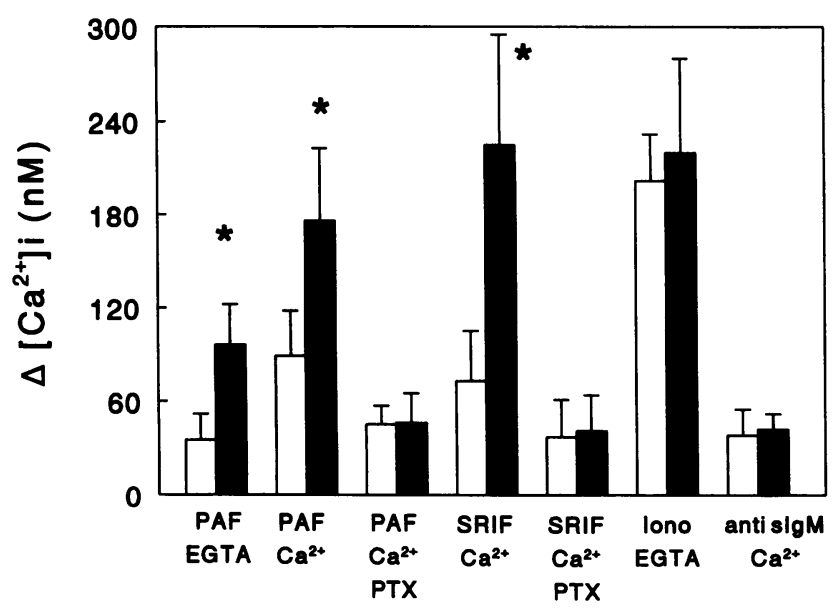

Figure 3. Effects of PAF, somatostatin, ionomycin, and anti-sIgM on $\left[\mathrm{Ca}^{2+}\right]_{\mathrm{i}}$ in NT and HT cell lines. Shown is the mean $( \pm \mathrm{SD})$ rise in $\left[\mathrm{Ca}^{2+}\right]_{\mathrm{i}}$ above basal values in NT (open columns) and HT (filled columns) cell lines upon stimulation with $0.1 \mu \mathrm{M}$ PAF (6 NT and 6 HT cell lines), $0.1 \mu \mathrm{M}$ somatostatin (SRIF ; $4 \mathrm{NT}$ and 4 HT cell lines), 10 $\mu \mathrm{M}$ ionomycin (Iono; $6 \mathrm{NT}$ and $6 \mathrm{HT}$ cell lines), or $10 \mu \mathrm{g} / \mathrm{ml}$ antisIgM ( 3 NT and 3 HT cell lines). Cells were stimulated with the respective agents in either the presence of $1 \mathrm{mM}$ extracellular $\mathrm{Ca}^{2+}$ $\left(\mathrm{Ca}^{2+}\right)$ or after chelating $\mathrm{Ca}^{2+}$ with $5 \mathrm{mM}$ EGTA (EGTA). Where indicated, cells were pretreated with $100 \mathrm{ng} / \mathrm{ml}$ PTX for $24 \mathrm{~h}$.* Significantly different from NT cell lines at $P<0.02$.

significantly $(P<0.05)$ lower at all time points and averaged $109 \pm 8,110 \pm 2$, and $109 \pm 2 \%$, respectively, of unstimulated controls. To rule out that these results could be explained by differences in total PLC activity, we determined $\mathrm{PIP}_{2}$ hydrolysis in cytosol and membrane fractions of three NT and three HT cell lines. In cytosolic fractions of NT and HT cell lines, PIP $_{2}$ hydrolysis averaged $11.2 \pm 0.8$ and $12.2 \pm 2.0 \mathrm{pmol} \times \mathrm{min}^{-1}$ $\times$ mg protein $^{-1}$, respectively. These values were lower in membrane preparations and averaged $2.8 \pm 0.9$ and $3.5 \pm 1.4$ pmol $\times$ min $^{-1} \times$ mg protein $^{-1}$ in NT and HT cell lines, respectively. Finally, we compared $\mathrm{IP}_{3}$ formation in intact and digitoninpermeabilized cells upon stimulation by PAF and the stable GTP analogue GTP $\gamma$ S, respectively. PAF $(0.1 \mu \mathrm{M})$ increased $\mathrm{IP}_{3}$ formation to $110 \pm 2$ and to $123 \pm 4 \%$ of controls $(P<0.025)$ in NT and HT cell lines, respectively (Fig. 4). On the other hand, GTP $\gamma \mathrm{S}(100 \mu \mathrm{M})$ caused identical increases in $\mathrm{IP}_{3}$ formation in NT and HT cell lines, averaging $128 \pm 12$ and $131 \pm 14 \%$ of controls, respectively. These data suggest that neither the totally available nor the total G protein-activated PLC activity can account for the observed differences in receptor-induced $\mathrm{IP}_{3}$ formation and $\mathrm{Ca}^{2+}$ mobilization in NT and HT cell lines.

Expression and activation of $G$ proteins. Using an anti- $\alpha_{\mathrm{i}}$ common antibody (10), we could demonstrate that the PTX-sensitive $G$ proteins $G_{i 2}$ and $G_{i 3}$ are expressed in NT and HT cell lines. The expression of these $G$ proteins was further confirmed by reverse-transcription PCR. Quantitative immunoblot analysis revealed that the expression of $\alpha_{\mathrm{i} 2}$ and $\alpha_{\mathrm{i} 3}$ was variable in different NT and HT cell lines. However, in repeated experiments there was no trend for an overexpression of $\alpha_{\mathrm{i} 2}$ and $\alpha_{\mathrm{i} 3}$ in HT cell lines (data not shown). Fig. 5 shows a representative result of an ADP-ribosylation experiment performed on membranes from four different NT and HT cell lines. This autoradiogram displays the typical variation of PTX substrates in NT and HT

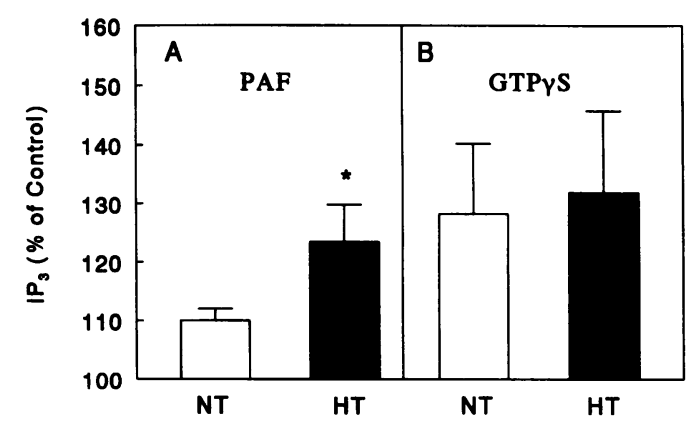

Figure 4. Effects of PAF and GTP $\gamma \mathrm{S}$ on $\mathrm{IP}_{3}$ formation in NT and HT cell lines. Formation of $\mathrm{IP}_{3}$ was determined in NT (open columns) and HT (filled columns) cell lines prelabeled with myo- $\left[2-{ }^{3} \mathrm{H}\right]$ inositol as described in Methods. Shown in $A$ is the $\mathrm{IP}_{3}$ formation upon intact cell stimulation with PAF $(0.1 \mu \mathrm{M} ; 30 \mathrm{~s})$ and in $B \mathrm{IP}_{3}$ formation upon stimulation of digitonin-permeabilized cells with GTP $\gamma \mathrm{S}(100 \mu \mathrm{M} ; 30$ s). Displayed is the formation of $\mathrm{IP}_{3}$ as percentage of controls, i.e., cells treated for $30 \mathrm{~s}$ with the respective solvents. Each column reflects the mean of three independent experiments performed in duplicate on five NT and five HT cell lines. There was no significant difference in the uptake of myo- $\left[2-{ }^{3} \mathrm{H}\right]$ inositol between the different cell lines. $* P<$ 0.05 .

cell lines. Again, these experiments yielded no evidence for a differential expression of PTX-sensitive G proteins in NT and HT cell lines. Subsequently, we used a third approach for $G$ protein quantification (19), i.e., we determined the binding of GTP $\gamma \mathrm{S}$ to membranes prepared from NT and HT cell lines. As illustrated in Fig. 6, there was no difference in GTP $\gamma \mathrm{S}$ binding capacity or affinity between NT and HT cell lines. Scatchard plot analysis of GTP $\gamma \mathrm{S}$ binding to membranes of 6 NT and 6 HT cell lines yielded identical $K_{\mathrm{d}}$ values of $5.1 \pm 1.1$ and $4.9 \pm 1.5$ $\mathrm{nM}$, respectively, and similar $B_{\max }$ values of $27.8 \pm 7.3$ and $21.5 \pm 2.4 \mathrm{pmol} / \mathrm{mg}$ protein, respectively. Taken together, these results argue against an overexpression of G proteins in HT or differences in GTP affinity, at least under unstimulated conditions.

Finally, we studied whether receptor-induced $G$ protein activation is different between NT and HT cell lines by measuring PAF-induced binding of GTP $\gamma \mathrm{S}$ to permeabilized cells. In all HT cell lines studied, binding of GTP $\gamma$ S induced by PAF $(0.1$ $\mu \mathrm{M}$ ) was distinctly enhanced compared with NT cells (Fig. 7 $A$ ). Whereas PAF stimulated GTP $\gamma$ S binding by $18.1 \pm 3.1 \%$ (mean \pm SEM) above basal in NT cell lines, this value averaged

$\mathrm{kD}$

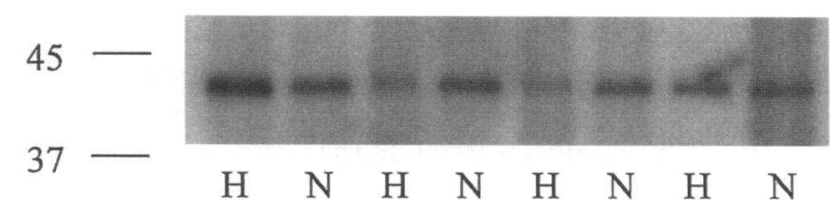

Figure 5. Quantification of PTX substrates in membranes from NT and HT cell lines. ADP-ribosylation studies were conducted as detailed in Methods. Displayed is a representative autoradiogram obtained from four different NT $(N)$ and HT $(H)$ cell lines. Similar experiments were performed in triplicate on membranes from six different NT and HT cell lines which yielded comparable results. The amount of PTX substrates was not significantly different in all NT and HT membrane preparations examined. 


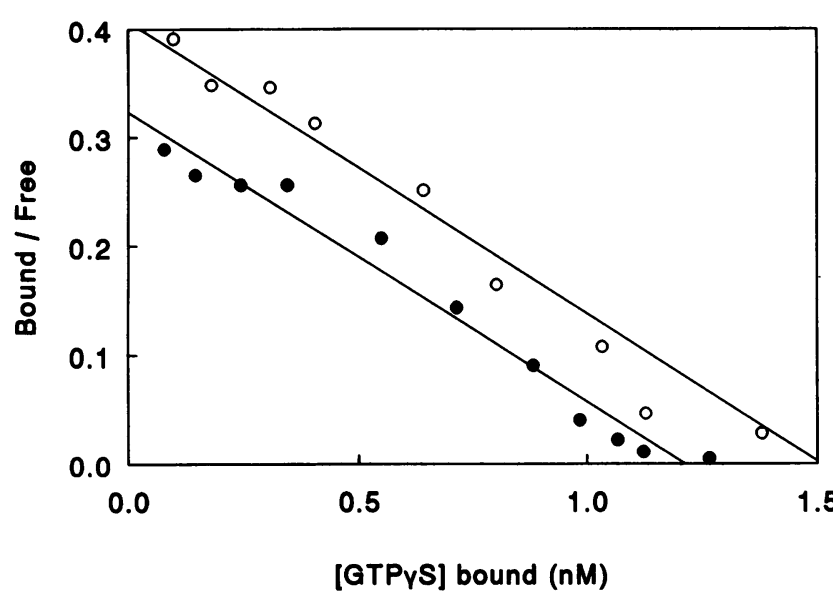

Figure 6. $\left[{ }^{35} \mathrm{~S}\right] \mathrm{GTP} \gamma \mathrm{S}$ binding to membranes from NT and HT cell lines was determined as detailed in Methods. Displayed are Scatchard plots of a representative experiment of $\left[{ }^{35} \mathrm{~S}\right] \mathrm{GTP} \gamma \mathrm{S}$ binding to membranes from an NT (O) and an HT $(\bullet)$ cell line. The straight lines were obtained from linear regression analysis of the corresponding data points. Quantitative analysis of similar binding data from six NT and six HT cell lines is given in Results.

46.1 $\pm 4.7 \%(P<0.001)$ in HT cell lines. These results were highly reproducible in at least three independent experiments on each cell line. PAF-induced binding of GTP $\gamma \mathrm{S}$ was completely abrogated in cells pretreated with PTX $(100 \mathrm{ng} / \mathrm{ml} ; 24 \mathrm{~h})$ (data not shown), indicating that this method actually determines the activation of PTX-sensitive G proteins. Basal binding of GTP $\gamma \mathrm{S}$ to permeabilized NT and HT cell lines, on the other hand, was not significantly different (not shown), which again argues against differences in $\mathbf{G}$ protein expression. Furthermore, permeabilized NT and HT cells were stimulated with the peptide, mastoparan-7, which directly activates $G$ proteins in the absence of hormones, potentially by mimicking agonist-activated receptors (21-23). Mastoparan-7-induced GTP $\gamma S$ binding was completely PTX sensitive (data not shown), indicating that this peptide primarily activated $\mathrm{G}_{\mathrm{i}}$-type proteins in permeabilized lymphoblasts. Stimulation of GTP $\gamma \mathrm{S}$ binding by mastoparan-7 was enhanced in HT cell lines (Fig. 7 B). Whereas mastoparan$7(25 \mu \mathrm{M})$ increased GTP $\gamma \mathrm{S}$ binding by $43 \pm 8 \%$ in NT cell lines, this value was significantly $(P<0.001)$ higher in HT cell lines and averaged $110 \pm 25 \%$.

\section{Discussion}

Rationale of the study. Enhanced NHE activity has been observed frequently in different blood cells of patients with EH (1). We have immortalized lymphocytes from patients with EH and high NHE activity (HT cells) and normotensive controls with low NHE activity (NT cells). The different NHE activity phenotypes persisted in these immortalized cell lines even after prolonged cell culture (3). It became clear, however, that neither an NHE overexpression nor a structural change of this transport protein could satisfactorily explain this difference (3). In addition to enhanced NHE activity, the HT cell lines proliferated distinctly faster than those from NT controls. It was tempting to speculate that the exquisite $\mathrm{pH}$ regulation in HT cell lines would be growth permissive and, therefore, we initially proposed a direct link between enhanced NHE activity and

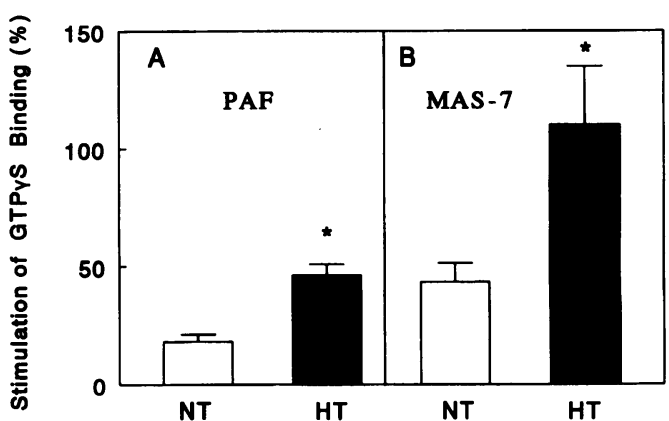

Figure 7. PAF- and mastoparan-7-stimulated binding of $\left[{ }^{35} \mathrm{~S}\right] \mathrm{GTP} \gamma \mathrm{S}$ to permeabilized NT and HT cell lines. Cells permeabilized with 10 $\mu \mathrm{M}$ digitonin were stimulated with $\mathrm{PAF}(0.1 \mu \mathrm{M})(A)$ or mastoparan$7(M A S-7 ; 25 \mu \mathrm{M})(B)$ for $1 \mathrm{~min}$ followed by addition of $\left[{ }^{35} \mathrm{~S}\right] \mathrm{GTP} \gamma \mathrm{S}$ $(10 \mathrm{nM})$. The binding reaction proceeded for another $10 \mathrm{~min}$. For further details see Methods. The data represent the percent increase in $\left[{ }^{35} \mathrm{~S}\right] \mathrm{GTP} \gamma \mathrm{S}$ binding over that measured in cells incubated with the respective solvents only. Each column reflects means \pm SEM of at least two independent determinations performed in triplicate on each cell line. A total of six NT and six HT cell lines was used for all experiments. $* P<0.001$.

enhanced cell proliferation (3). However, recent studies make this earlier notion unlikely, since the proliferation of the established cell lines remained unaffected by blockade of NHE activity by ethylisopropylamiloride or at extracellular $\mathrm{pH}$ values, when NHE no longer takes part in intracellular pH regulation (4).

The serum-stimulated growth of HT cell lines was markedly more inhibited by PTX treatment than that of NT cell lines, suggesting an enhanced signal transduction via PTX-sensitive $\mathrm{G}$ proteins in HT cells (4). Since this growth stimulus consists of an undefined mixture of growth factors, it was mandatory to compare cell growth and signal transduction in NT and HT cells using a single, well-defined agonist which fulfills two prerequisites. First, this agonist should activate B cells via PTX-sensitive $\mathrm{G}$ proteins, and, second, it should induce lymphoblast proliferation. This is the only reason why most of the experiments described here were conducted using PAF as cell stimulus. The PTX-sensitive pathways that ultimately result in lymphoblast proliferation upon stimulation by PAF have been well characterized in the past (5-9). In fact, stimulation by PAF caused an enhanced proliferation of HT cells which was PTX sensitive and was not caused by an overexpression of PAF receptors.

Enhanced $\mathrm{Ca}^{2+}$ mobilization in $\mathrm{HT}$ cells. Given the established regulation of the NHE-1 by $\mathrm{Ca}^{2+} /$ calmodulin $(24,25)$ in alliance with a presumed tight correlation between increased $\left[\mathrm{Ca}^{2+}\right]_{\mathrm{i}}$ and enhanced NHE activity in EH (26-29), we focused part of the experiments on PAF-induced $\mathrm{Ca}^{2+}$ signals in NT and $\mathrm{HT}$ cell lines. Whereas basal $\left[\mathrm{Ca}^{2+}\right]_{\mathrm{i}}$ was not significantly different in NT and HT cell lines, PAF-induced $\mathrm{Ca}^{2+}$ signals were twofold enhanced in HT cell lines both in the absence and presence of extracellular $\mathrm{Ca}^{2+}$. The $\mathrm{EC}_{50}$ values for the PAFinduced $\mathrm{Ca}^{2+}$ rises were very similar in NT and HT cell lines. This observation, together with the almost identical $K_{\mathrm{d}}$ values of PAF binding to NT and HT cells, strongly implies that the differences in $\mathrm{Ca}^{2+}$ mobilization cannot be explained by corresponding changes in PAF receptor affinities. Furthermore, the observation that similar differences were observed with somatostatin argues against an abnormality specifically or exclusively related to PAF receptor function. The finding that $\mathrm{Ca}^{2+}$ rises 
evoked by an anti-sIgM antibody, which is known to be PTX insensitive (20), were very similar in NT and HT cell lines supports the hypothesis that signal transduction via $\mathrm{G}$ proteincoupled receptors is specifically enhanced in HT cell lines. The twofold enhanced $\mathrm{Ca}^{2+}$ signals in HT cells corresponded well with quantitatively similar differences in PAF-stimulated $\mathrm{IP}_{3}$ formation. Two lines of evidence suggest that this latter effect is not due to corresponding differences in PLC activity. First, total PLC activities in cytosol and membranes were not significantly different in NT and HT cell lines. Second, $\mathrm{IP}_{3}$ formation was almost identical upon stimulation of $G$ proteins with the stable GTP analogue GTP $\gamma$ S in permeabilized NT and HT cell lines.

Enhanced $G$ protein activation in $H T$ cell lines. The differences in $\mathrm{Ca}^{2+}$ signals caused by PAF and somatostatin in HT and NT cell lines were abrogated upon PTX treatment, which may suggest that only PTX-sensitive, but not PTX-insensitive, signal transduction pathways are enhanced in HT cells. It is not yet known which $G$ proteins are activated by PAF and somatostatin in lymphoblasts. Our functional data at least imply that both receptors predominantly bind to PTX-sensitive and to a minor extent to PTX-insensitive G proteins. This can be inferred from the fact that the $\mathrm{Ca}^{2+}$ signals in lymphoblasts pretreated with a rather high concentration of PTX were strongly reduced but not completely abolished. Thus, part of the $\mathrm{Ca}^{2+}$ signals may be mediated via PTX-insensitive $G$ proteins such as $\mathrm{G}_{\mathrm{q} / 11}$.

These findings led us to investigate in more detail the activation of PTX-sensitive G proteins in NT and HT cell lines. We determined an almost threefold enhanced, completely PTX-sensitive PAF-induced binding of GTP $\gamma \mathrm{S}$ to HT cell lines, which is strongly suggestive of an enhanced activation of $G_{i}$-type heterotrimeric $\mathrm{G}$ proteins. Compatible findings were obtained after direct $\mathrm{G}$ protein stimulation with mastoparan-7, which was also completely PTX sensitive. Thus, NT and HT cell lines differ significantly with regard to activation of PTX-sensitive G proteins, and these differences could also explain the differences in agonist-evoked $\mathrm{IP}_{3}$ formation, $\mathrm{Ca}^{2+}$ mobilization, and cell proliferation reported here and earlier. The $G$ proteins involved most likely represent the $G_{i 2}$ and $G_{i 3}$ isoforms of PTX-sensitive $G$ proteins because other PTX-sensitive $G$ proteins, e.g., $G_{i l}$ or $\mathrm{G}_{\mathrm{o}}$ are not expressed in B lymphoblasts (30). Two major reasons could explain the enhanced $G$ protein activation in HT cell lines. First, the expression of PTX-sensitive G proteins could be enhanced in these cells, or, second, the activation of PTXsensitive $\mathrm{G}$ proteins could be facilitated in HT cell lines. The findings reported here argue against an overexpression of $G$ proteins in HT cell lines, since immunoblotting and ADP-ribosylation studies yielded no evidence for increased amounts of $\mathrm{G}_{\mathrm{i}}$-type $\mathrm{G}$ proteins. In addition, the unstimulated binding of GTP $\gamma$ S to membranes and permeabilized cells was virtually identical in NT and HT cell lines. Although the exact identity of the labeled $\mathrm{G}$ proteins remains to be determined, earlier studies strongly suggest that this method primarily quantifies the amounts of $G_{i}$-type $G$ proteins. First, these $G$ proteins are generally most abundant $(31,32)$, and, second, $G_{i}$-type $G$ proteins most easily exchange bound GDP against GTP in the unstimulated state when compared with other heterotrimeric as well as low molecular weight $G$ proteins (19). Studies on human platelets have ruled out an overexpression of $G_{i}$ proteins in hypertensive patients (33). Therefore, other reasons may account for the enhanced $G$ protein activation in HT cells. These could include structural changes in PTX-sensitive heterotrimeric $G$ protein subunits which enhance their activation by agonistactivated receptors. Alternatively, PTX-sensitive G proteins or a subset thereof present in HT cells could be differentially regulated, e.g., by phosphorylation (34). These possibilities are currently under investigation.

In conclusion, we have established immortalized HT cell lines which differ from their NT counterparts by an enhanced NHE activity and, most notably, by an enhanced proliferation. The data of this study suggest that the molecular reason for these cellular abnormalities could stem from an enhanced activation of PTX-sensitive $\mathrm{G}$ proteins. Future studies will have to identify the $G$ protein( $s$ ) involved and resolve the mechanisms which cause the enhanced $G$ protein activation.

\section{Acknowledgments}

We thank Dr. Karsten Spicher for anti- $\alpha_{\mathrm{i}}$ antibodies. We gratefully acknowledge Gerlinde Siffert and Anne-Marie Sprungmann for their expert assistance in experimentation.

This study was supported by the Deutsche Forschungsgemeinschaft and by the Ministerium für Wissenschaft and Forschung NRW.

\section{References}

1. Rosskopf, D., R. Düsing, and W. Siffert. 1993. Membrane sodium-proton exchange and primary hypertension. Hypertension (Dallas). 21:607-617.

2. Canessa, M., K. Morgan, R. Goldszer, T. J. Moore, and A. Spalvins. 1991. Kinetic abnormalities of the red blood cell sodium-proton exchange in hypertensive patients. Hypertension (Dallas). 17:340-348

3. Rosskopf, D., E. Frömter, and W. Siffert. 1993. Hypertensive sodiumproton exchanger phenotype persists in immortalized lymphoblasts from essential hypertensive patients. A cell culture model for human hypertension. J. Clin. Invest. 92:2553-2559.

4. Rosskopf, D., K.-J. Schröder, and W. Siffert. 1995. Role of $\mathrm{Na}^{+} / \mathrm{H}^{+}$exchange in the proliferation of immortalised lymphoblasts from patients with essential hypertension and normotensive subjects. Cardiovasc. Res. 29:254-259.

5. Schulam, P. G., A. Kuruvilla, G. Putcha, L. Mangus, J. Franklin-Johnson, and W. T. Shearer. 1991. Platelet-activating factor induces phospholipid turnover, calcium flux, arachidonic acid liberation, eicosanoid generation, and oncogene expression in a human B cell line. J. Immunol. 146:1642-1648.

6. Kuruvilla, A., G. Putcha, E. Poulos, and W. T. Shearer. 1993. Tyrosine phosphorylation of phospholipase $\mathrm{C}$ concomitant with its activation by plateletactivating factor in a human B cell line. J. Immunol. 151:637-648.

7. Mazer, B. D., H. Sawami, A. Tordai, and E. W. Gelfand. 1992. Plateletactivating factor-mediated transmembrane signaling in human $B$ lymphocytes is regulated through a pertussis- and cholera toxin-sensitive pathway. J. Clin. Invest. 90:759-765.

8. Mazer, B., J. Domenico, H. Sawami, and E. W. Gelfand. 1991. Plateletactivating factor induces an increase in intracellular calcium and expression of regulatory genes in human B lymphoblastoid cells. J. Immunol. 146:1914-1920.

9. Franklin, R. A., B. Mazer, H. Sawami, G. B. Mills, N. Terada, J. J. Lucas, and E. W. Gelfand. 1993. Platelet-activating factor triggers the phosphorylation and activation of MAP-2 kinase and S6 peptide kinase activity in human B cell lines. J. Immunol. 151:1802-1810.

10. Laugwitz, K.-L., S. Offermanns, K. Spicher, and G. Schultz. 1993. $\mu$ and $\delta$ opioid receptors differentially couple to $\mathrm{G}$ protein subtypes in membranes of human neuroblastoma SH-SY5Y cells. Neuron. 10:233-242.

11. Rosskopf, D., G. Siffert, U. Osswald, K. Witte, R. Duising, J. W. N. Akkerman, and W. Siffert. 1992. Platelet $\mathrm{Na}^{+} / \mathrm{H}^{+}$exchange activity in normotensive and hypertensive subjects: effect of enalapril therapy upon antiport activity. J. Hypertens. 10:839-847.

12. Kovar, J., and F. Franek. 1986. Serum-free medium for hybridoma and parental myeloma cell cultivation. Methods Enzymol. 121:277-292.

13. Bradford, M. M. 1976. A rapid and sensitive method for quantitation of microgram quantities of protein utilizing the principle of protein-dye binding. Anal. Biochem. 72:248-254.

14. Laemmli, U. K. 1970. Cleavage of structural proteins during the assembly of the head of bacteriophage $T_{4}$. Nature (Lond.). 227:680-685.

15. Milligan, G. 1994. Specificity and functional applications of antipeptide antisera which identify G-protein $\alpha$ subunits. Methods Enzymol. 237:268-282.

16. Carty, D. J. 1994. Pertussis toxin-catalyzed ADP-ribosylation of G proteins. Methods Enzymol. 237:63-70. 
17. Valone, F. H. 1992. Binding of platelet-activating factor 1- $O$-alkyl-2acetyl-sn-glycero-3-phosphorylcholine to intact platelets and platelet membranes. Methods Enzymol. 215:224-228.

18. Wieland, T., K. Liedel, S. Kaldenberg-Stasch, D. Meyer zu Heringdorf, M. Schmidt, and K. H. Jakobs. 1995. Analysis of receptor-G protein interactions in permeabilized cells. Naunyn-Schmiedeberg's Arch. Pharmacol. 351:329-336.

19. Wieland, T., and K. H. Jakobs. 1994. Measurement of receptor-stimulated guanosine $5^{\prime}-O$-(gamma-Thio) triphosphate binding by $\mathrm{G}$ proteins. Methods $\mathrm{En}$ zymol. 237:3-13.

20. Cushley, W., and M. M. Harnett. 1993. Cellular signalling mechanisms in B lymphocytes. Biochem. J. 292:313-332.

21. Ross, E. M., and T. Higashijima. 1994. Regulation of G-protein activation by mastoparan and other cationic peptides. Methods Enzymol. 237:27-38.

22. Higashijima, T., J. Burnier, and E. M. Ross. 1990. Regulation of $G_{i}$ and $\mathrm{G}_{\mathrm{o}}$ by mastoparan, related amphiphilic peptides, and hydrophobic amines. J. Biol. Chem. 265:14176-14186.

23. Higashijima, T. S. Uzu, T. Nakajima, and E. M. Ross. 1988. Mastoparan, a peptide toxin from wasp venom, mimics receptors by activating GTP-binding regulatory proteins (G proteins). J. Biol. Chem. 263:6491-6494.

24. Bertrand, B., S. Wakabayashi, T. Ikeda, J. Pouysségur, and M. Shigekawa. 1994. The $\mathrm{Na}^{+} / \mathrm{H}^{+}$exchanger isoform 1 (NHE1) is a novel member of the calmodulin-binding proteins. Identification and characterization of calmodulinbinding sites. J. Biol. Chem. 269:13703-13709.

25. Wakabayashi, S., B. Bertrand, T. Ikeda, J. Pouysségur, and M. Shigekawa.
1994. Mutation of calmodulin-binding site renders the $\mathrm{Na}^{+} / \mathrm{H}^{+}$exchanger (NHE1) highly $\mathrm{H}^{+}$-sensitive and $\mathrm{Ca}^{2+}$ regulation-defective. J. Biol. Chem 269:13710-13715.

26. Aviv, A. 1988. The link between cytosolic $\mathrm{Ca}^{2+}$ and the $\mathrm{Na}^{+} / \mathrm{H}^{+}$antiport: a unifying factor for essential hypertension. J. Hypertens. 6:685-691.

27. Aviv, A., and A. Livne. 1988. The $\mathrm{Na}^{+} / \mathrm{H}^{+}$antiport, cytosolic free $\mathrm{Ca}^{2+}$ and essential hypertension: a hypothesis. Am. J. Hypertens. 1:410-413.

28. Aviv, A. 1992. The roles of cell $\mathrm{Ca}^{2+}$, protein kinase $\mathrm{C}$ and the $\mathrm{Na}^{+} / \mathrm{H}^{+}$ antiport in the development of hypertension and insulin resistance. J. Am. Soc. Nephrol. 3:1049-1063.

29. Aviv, A. 1994. Cytosolic $\mathrm{Ca}^{2+}, \mathrm{Na}^{+} / \mathrm{H}^{+}$antiport, protein kinase $\mathrm{C}$ trio in essential hypertension. Am. J. Hypertens. 7:205-212.

30. Matsuoka, M., Y. Kaziro, S. Asano, and E. Ogata. 1993. Analysis of the expression of seven $\mathrm{G}$ protein alpha subunit genes in hematopoietic cells. Am. $J$. Med. Sci. 306:89-93.

31. Birnbaumer, L. 1990. G proteins in signal transduction. Annu. Rev. Pharmacol. Toxicol. 30:675-705.

32. Birnbaumer, L. 1992. Receptor-to-effector signaling through $G$ proteins: roles for beta gamma dimers as well as $\alpha$ subunits. Cell. 71:1069-1072.

33. McLellan, A. R., G. Milligan, M. D. Houslay, and J. M. C. Connell. 1993. G-proteins in essential hypertension: a study on human platelet plasma membranes. J. Hypertens. 11:543-549.

34. Houslay, M. D. 1993. Phosphorylation of heterotrimeric G-protein. In GTPases in Biology II. B. F. Dickey and L. Birnbaumer, editors. Springer Verlag, Berlin. 147-165. 